\title{
State activism and the hidden incentives behind bank acquisitions ${ }^{\text {is }}$
}

\author{
Christopher Marquis ${ }^{\mathrm{a}, *}$, Doug Guthrie ${ }^{\mathrm{b}}$, Juan Almandoz ${ }^{\mathrm{c}}$ \\ a Harvard University, 333 Morgan Hall, Boston, MA 02163, United States \\ ${ }^{\mathrm{b}}$ The George Washington University, 2201 G Street, NW, Washington, DC 20052l, United States \\ ${ }^{\mathrm{c}}$ Harvard University, Soldiers Field, Boston, MA 02163, United States
}

\section{A R T I C L E I N F O}

\section{Article history:}

Received 22 October 2009

Revised 17 April 2011

Accepted 6 July 2011

Available online 23 July 2011

\section{Keywords:}

Banking consolidation

Regulation

Historical research

Institutional theory

\begin{abstract}
A B S T R A C T
A number of studies have shown that, as a result of the ambiguity of US legal mandates, organizations have considerable latitude in how they comply with regulations. In this paper, we address how the different agendas of the federal and state governments increase ambiguities in state-firm relations and how states are interested actors in creating opportunities for firms to navigate the federal legislation. We analyze the institutional forces behind bank acquisitions within and across state lines in order to illuminate the ways that US states take advantage of federal ambiguity and are able to shape corporate practices to their benefit. We specifically examine how patterns of bank acquisitions are shaped by the crucial relationship between the federal Community Reinvestment Act (CRA) and a littleunderstood provision in the federal tax code that is implemented at the state level, the Low-Income Housing Tax Credit (LIHTC). The relationship is complex because, while the federal government uses the CRA to control bank acquisition activity, states promote use of the LIHTC, through which banks can address federal CRA concerns, and thereby promote bank acquisitions in their jurisdictions. Thus, our findings suggest that the implementation of social legislation at one level in a federal regulatory system undermines the mechanisms of social legislation at another level. We use archival research and in-depth interviews to examine the interaction between these institutional processes and formulate hypotheses that predict the ways in which bank acquisitions are constrained by banks' CRA ratings and the way states in turn help banks overcome their CRA constraints. Quantitative analyses of all bank acquisitions in the United States from 1990-2000 largely support these hypotheses.
\end{abstract}

(c) 2011 Elsevier Inc. All rights reserved.

\section{Introduction}

US states must balance many, sometimes conflicting constituencies when creating social policy. On the one hand they are guardians of the public good, and on the other hand, they must encourage business expansion and growth to develop vibrant local economies. In this paper, we explore the complex and multi-layered process in which US states regulate the corporate sector and facilitate the consolidation of business and capital. Key changes in the US federal tax code over the last quartercentury have allowed states to find new ways to balance and integrate the dual missions of protecting the public good and encouraging business expansion. In the case we examine, states have been able to take advantage of a federal tax credit system to help corporations deal with an ambiguous regulatory issue that constrains their ability to acquire other firms. Thus, this case shows that one of the ways for states to consolidate business and capital is to help corporations deal with

\footnotetext{
We thank Mark Mizruchi for his comments on a prior version of this paper.

* Corresponding author.

E-mail addresses: cmarquis@hbs.edu (C. Marquis), guthrie@gwu.edu (D. Guthrie), jalmandoz@hbs.edu (J. Almandoz).
} 
the ambiguity of federal regulations. This state activity then shapes organizations' behaviors in this sector, and as a result, industry structure reflects variation in state activism.

Organizational theory has long been interested in how legal environments influence corporate activities. Shifts in federal laws have been shown to cause corporations to interpret their environments differently and to influence the economic decisions of organizations. Research has shown that firm structure (Fligstein, 1990; Roy, 1997; Zorn, 2004), strategy (Davis et al., 1994), and even internal policy (Dobbin et al., 1993; Edelman, 1990, 1992; Sutton et al., 1994) are shaped by legal changes at the federal level. For example, Fligstein (1990) showed how a number of federal regulatory changes in the twentieth century drove the evolution of the corporate form. Similarly, legislation during the Reagan era led to changes in the legitimate corporate structure, which then shaped corporate acquisition and divestiture patterns (Davis et al., 1994). Some scholars have observed the effects of federal laws and regulations on organizations to be so powerful as to matter above and beyond economic efficiency (Roy, 1997).

A number of studies have examined the effects of state laws, either as microcosms to understand regulatory effects on organizations more generally (e.g. Dobbin and Dowd, 1997, 2000; Haveman and Rao, 1997), or across states to show how regulatory environments differ (Guthrie and Roth, 1999a; Schneiberg and Bartley, 2001; Wade et al., 1998). An important line of research shows how US states are in economic competition; they are thus interested in promoting their own banks as a way of supporting business within their borders. Campbell and Lindberg (1990), for example, maintain that laws and regulations are a basis for competition among states to attract corporate headquarters and plant locations. Southern states, for instance, offered more relaxed and, hence, favorable property rights to consolidate industries. And New Jersey and later Delaware also passed permissive corporate laws to consolidate the headquarters of large corporations. Many legal scholars have similarly described states' regulation and facilitation of corporate entry to and exit from their local economies (Bebchuk, 1992; Romano, 1987, 1993; Steiner, 1975).

Both these prior sets of analyses-one focused on federal regulatory effects on firms and one on state-level facilitation of business activity-are limited in that they typically only consider one side of the coin. But the relationships among federal legislation, states, and firms is considerably more complex. Research on specific cases of how these institutional and organizational levels of analysis interact illuminates important facts about the ways in which organizations and states navigate institutional change. We argue that federal and state regulatory processes are, in some cases, interdependent, and that states have an important role in how firms interpret and respond to federal law. Other researchers have shown that federal law is typically ambiguous and that firms are often interpreters and shapers of law (e.g. Dobbin et al., 1993; Dobbin and Sutton, 1998; Edelman, 1992). For instance, prior analyses suggest that firm response to law is a result of organizational trial and error or of the adoption of "best practices" (Kalev et al., 2006). We suggest that US states play an active role in helping organizations address federal mandates. We use the term state activism to describe how states are active players in the creation, maintenance, and creative appropriation of certain institutions that either consolidate or regulate businesses within their borders. By helping organizations address federal ambiguity, states thus shape organizational activity and the structure of industries.

Consolidation in the twentieth century US banking industry is a good setting to examine the intersection between organizations and their state and federal legal environments for a number of reasons. First, the banking industry is highly regulated at both levels. The influence of laws on the structure of banks and the banking industry is explored in a large literature in both economics and sociology (e.g., Berger et al., 1995; Davis and Mizruchi, 1999; Marquis and Huang, 2009, 2010). Many other US industries including transportation, communication, utilities, health care, and agriculture that, like banking, were once highly regulated have been significantly deregulated since the 1980s (Lounsbury et al., 1998).

Second, both types of regulators have been focused on the issue of bank consolidation. Regulatory limits on bank expansion that grew out of an historical fear of concentrated capital and banking persisted for much of US history (Roe, 1994). Communities resisted the consolidation of banks in their area, since larger banks were perceived as invaders beholden to the economic interests of distant corporations, and were less responsive than smaller local banks to the needs of communities (Marquis and Lounsbury, 2007). Yet states' economies and economic growth hinge on a large and vibrant banking sector (Dehejia and Lleras-Muney, 2003). Economies of scale allow consolidated banks to provide a much wider array of services at lower rates to local businesses; therefore, states bent on promoting local economic growth have an interest in promoting bank consolidation within their borders.

Third, regulations of the banking industry, especially those at the federal level connecting acquisition activity and underserved community lending, were ambiguous and complex, which gave state regulators some leverage to intervene in the way banks interpreted and responded to those regulations. Our empirical analysis begins with a complex institutional history of a wave of bank regulation that began in the 1970s that we later quantitatively show has influenced the bank acquisition wave of the 1990s. Corporate acquisitions have long held the interest of organizational scholars (Davis and Stout, 1992; Palmer et al., 1995; Stearns and Allan, 1996; Marquis and Huang, 2010). The banking case is unique, however, because government approval of acquisitions is contingent on whether banks serve their local communities as mandated by the Community Reinvestment Act (CRA), which was passed in 1977 to compel banks to bring banking services and resources to lowincome communities. The CRA is a classic example of an ambiguous law in that specific criteria for compliance are not specified, but there are many ways banks can get credit for "serving" low-income communities. Traditionally these have included philanthropy, charitable activities, and access to services such as everyday consumer banking and personal and commercial loans. While prior research on legal ambiguity has highlighted how such laws can provide opportunities for organizations, we show how ambiguous CRA regulations provide a constraint on bank acquisition activities. 
A new approach for banks to fulfill CRA requirements emerged in the late 1980s, providing an important tool for state regulators to assist banks in their acquisition activities. It was a small, experimental provision of the Tax Reform Act of 1986 called the Low-Income Housing Tax Credit (LIHTC). Legislators did not realize at the time (because the LIHTC was not originally intended for corporate use) that the LIHTC would by 1990 prove to be an extremely lucrative way to fulfill CRA obligations because it also afforded banks a double tax break that was previously unheard of in corporate and individual tax history (Guthrie, 2004; Guthrie and McQuarrie, 2005, 2006). Although the CRA and LIHTC are both federal laws, states control how active the LIHTC market is within their borders. States make available to banks LIHTC opportunities, which help them meet their CRA requirements in a cost-effective manner, and concurrently consolidate capital within their local economies. In the case of the CRA and LIHTC, regulatory action began at the federal level and state-level activism emerged, as an unintended consequence, to help corporations navigate the regulatory environment. We show that because they are ambiguous, federal CRA judgments constrain bank acquisitions; however activist states are able to use the LIHTC to help banks navigate the federal CRA requirements and as a result consolidate capital within their borders.

In the following section we review the literature in organizational theory on business-state relationships and on competition among states to attract business by creating a favorable economic environment. After that theoretical overview, we discuss the particular case of banking regulation, showing empirically the interplay of federal and state actors governing, and facilitating, bank acquisitions. The hypotheses proposed are informed by archival research of banking regulation over the last 30 years, including the congressional record, government and academic studies, and press accounts, accompanied by in-depth interviews with individuals working in this sector. We conclude with a discussion of our primary theoretical point-because federal regulations of corporations are ambiguous, in situations when states interests are in-line with corporations, activist states can find solutions that allow corporations to comply with the federal law in ways that may controvert the intended federal regulatory mechanisms.

\section{Theory and hypotheses}

Institutional theory, one of the most active areas of organizational research (e.g. see Mizruchi and Fein, 1999; Powell and DiMaggio, 1991), has shown that there are many ways that the state and law affect organizations. Investigators have assessed how public policy influences organizational structures, strategies, and competitive conditions (e.g., Davis et al., 1994; Dobbin and Dowd, 1997; Fligstein, 1990). Law within this framework has been categorized as having both coercive and normative influences. For example, Fligstein (1990) showed how the Celler-Kefauver Act of 1950, which prohibited vertical mergers, limited the options available to corporations and how one result was increased cross-industry acquisition activity and the rise of conglomerates. On the normative side, a number of studies have shown how changes in the legal environment in the wake of the Civil Rights Act of 1964 disposed organizations in the 1960s and early 1970s to adopt different organizational structures that signaled normative compliance with the emerging regulatory regime (Dobbin et al., 1993; Edelman, 1990, 1992; Sutton et al., 1994).

A key conceptual innovation of recent work in this area distinguishes between the effects of strong versus weak states (Jepperson and Meyer, 1991) and reveals how the effect of much US policy relies on organizational interpretation, and thus there are typically multiple ways firms can meet the legal requirements. For example, in a study of the effectiveness of firm anti-discrimination activities, Kalev et al. (2006) discussed how corporations' affirmative action and diversity policies designed in response to the Civil Rights Act are typically a result of experiments with different types of "best practices."

This focus of firms searching for different alternative responses to federal regulations is also described by Dobbin and Sutton (1998), and Edelman (1990, 1992). This body of work suggests that there are important state-level effects. For example, in their study of firm responses to federal legislation, the Dobbin and Sutton team (Dobbin et al., 1993; Dobbin and Sutton, 1998; Sutton et al., 1994; Sutton and Dobbin, 1996) draw their sample of firms from three different states to test the hypothesis that state-level legislative environments will cause firms to behave differently above and beyond the impact of federal legislative change. They consistently find that location in the State of California-with its comparatively liberal laws in support of workers' rights (compared to Virginia and New Jersey)-has a significant positive impact on the firm-level adoption of a variety of labor-oriented practices.

Similarly, in a national sample of firms, Guthrie and Roth (1999b) show that the specific language of state-level statutory law has an impact on what firms do within those states. Firms introduced new strategies of offering maternity leave benefits to circumvent the federal definition of gender neutrality in the workplace. State-level institutional environments provide a framework for this institutional innovation, but it is the firms that were the agents in these models of action.

This research has focused mostly on organizational interpretations of the best way to meet regulatory conditions. In both the Dobbin and Sutton and Guthrie and Roth studies, while states exist as separate institutional environments, the theoretical view begins with firms that are creatively experimenting with practices to navigate the often ambiguous and (at times) conflicting legislative mandates of both the federal and state systems.

However, another perspective is that state government may have an interest-economic or otherwise-in helping corporations circumvent the federally-regulated practice and therefore provide some of the tools to help corporations address their federal responsibilities. A number of research traditions have studied how state-level policy typically takes the form of facilitating as opposed to regulating economic activity. For much of US history, states engaged in "rivalistic state mercantilism" (Scheiber, 1981) whereby state governments acted to protect their own industries and attract outside economic 
interests by, for example, promoting state-based canals, banks, turnpikes, factories, and railroads to support important statebased industries. Campbell and Lindberg's (1990) discussion of the importance of the US states as economic actors and their role in the development of regionally distinct economies posits that laws were the basis of competition among states for corporate headquarters and plant locations. We noted earlier southern states' relaxation of property rights to attract industries and New Jersey's and Delaware's enactment of permissive corporate laws to attract corporate headquarters.

The facilitation of positive economic conditions for corporations has been widely explored in the legal literature on the corporation. A number of scholars have studied states' increasing deregulation of economic conditions to attract capital to their local economies (Bebchuk, 1992; Romano, 1987, 1993; Steiner, 1975), a condition that has created the euphemistic "race to the bottom" in the area of corporate deregulation, where states end up lining up with corporate interests more than with federal government or even community interests because they give greater primacy to state economic goals, which line up more with corporate interests. The argument here is that states compete to create vibrant economies and establish within their borders regulatory regimes favorable to corporations, thereby, according to this literature, facilitating as much as regulating corporate activity. ${ }^{1}$ Boeing's decision to move its headquarters from Seattle to Chicago in 2001, for example, was heavily influenced by the long-term tax package the City of Chicago and the State of Illinois were able to offer it relative to the less lucrative incentives offered by the competing cities of Denver, Colorado and Dallas, Texas. Tax advantages are but one way in which states can use the federal tax code to attract capital.

The case we describe below involves a part of the federal tax code that enables states to attract, retain and consolidate banking capital in a way that is much more hidden from public view, because banking consolidation may be controversial. We argue that states have more tools at their disposal than the simple tax abatements and the power to regulate or deregulate economic activity within their borders. States today are able, through the complex worlds of accounting, tax credits, work placement systems, and variations in local political systems, to employ many different strategic approaches to attracting and retaining capital, which may be less visible to certain opposing constituencies. Institutional change in the regulation of the banking industry is driven by a complex interplay of federal, state, and corporate interests. This is a process that unfolds over time, where corporations and states draw on an unanticipated application of a piece of federal legislation in an attempt to find a solution for dealing with an ambiguous and constraining federal regulation.

In the case and analyses we present here, an obscure piece of federal legislation (the LIHTC) that few in Congress expected would amount to much (much less offer any benefits for corporations) became an opportunity for a double tax break for the corporate sector and the catalyst for a dramatic increase in activity surrounding the development of low-income housing (Guthrie, 2004; Guthrie and McQuarrie, 2005, 2006). It also created an opportunity for states to promote consolidation and retain capital within their jurisdictions by promoting the use of this credit as a way to deal with the federal regulatory pressures of the CRA. Thus, as described above, we argue that the developments in the area of low-income housing had important consequences for banks in terms of rethinking their strategies for: (1) finding solutions for dealing with the regulatory pressures of the CRA that could hinder their acquisition activity and (2) seeking out the business opportunities presented by the low-income housing development market. This trend led, in turn, to states taking an activist approach to developing the market for low-income housing by promoting the LIHTC, which would provide banks with economic opportunities as well by bolstering their CRA ratings and shifting some of their cost of CRA compliance to the federal government.

\subsection{State policy and US bank expansion}

Throughout US history, the banking industry has been the focus of public fear of expansion and the associated concentration of capital (Roe, 1994) with the result that federal and state governments have taken a strong role in regulating bank growth and geographic spread (Marquis and Huang, 2009, 2010). Although the general public still did not approve of consolidated capital, as the twentieth century progressed it became clear that having larger banks might be in the states' economic interests because they could provide capital to help finance growth in other areas (Dehejia and Lleras-Muney, 2003). This led to tension in states' regulation of banking institutions. Owing to strong public support for a geographically limited banking industry, restrictive banking laws were popular in many states. But, because of banks importance to the state economy, as well as their informal power (Mizruchi, 1992; Davis and Mizruchi, 1999), states also had an incentive to devise means to allow banks to circumvent these restrictions to facilitate their expansion. Economies of scale allow larger banks to provide a much wider array of services at lower rates; therefore, states bent on promoting local economic growth may be invested in promoting bank consolidation within their borders.

Debate and legislative change around the control and growth of banks, particularly with respect to their ability to establish offices across state lines, persisted throughout the 1980s. By the late 1980s, a majority of US states permitted out-ofstate banks to operate within their borders. The federal government, taking an activist position and aiming for a consolidated US banking sector able to compete globally, essentially ended state restrictions on bank expansion with the passage in 1994 of the Riegle-Neal Interstate Banking and Branching Efficiency Act (Marquis and Lounsbury, 2007).

As we explain below, however, there remained throughout this period, federal regulatory barriers to bank expansion arising from the Community Reinvestment Act. But as we also show, the ambiguous nature of this regulation provided latitude

\footnotetext{
1 Local tax laws are an obvious example of this dynamic: while US corporations are all subject to the same federal tax rates, state-level corporate tax rates vary widely, ranging from $0 \%$ to $9.99 \%$, one of the many ways in which states attract corporations to their local economies.
} 
to banks with respect to how they could meet CRA requirements. Some states were creative actors and provided organizations a way around this restriction in order to effectively maintain sources of capital within their borders and continue the century-long trend of bank consolidation. Thus, our contention is that to understand the influence of ambiguous regulations designed for social purposes, it is incomplete to just look at actors' responses, but one must consider the interests behind other institutional forces that push or pull organizations toward different solutions.

\subsection{Federal regulation of community reinvestment}

By the early 1970s, many US cities were in crisis (e.g., Massey and Denton, 1992; Venkatesh, 2000; Wilson, 1987) and there was growing recognition that banks were partially to blame. Housing markets were significantly shaped by unfair lending practices, and "redlining" by banks became one of the hottest issues of the time as community activists began to exert pressure on legislators. ${ }^{2}$ To hold banks and other lending agencies accountable in the areas of mortgages and housing development, the US Congress passed the Fair Housing Act in 1968, the Equal Credit Opportunity Act in 1974, the Home Mortgage Disclosure Act (HMDA) in 1975, and the Community Reinvestment Act (CRA) in 1977. The HMDA and CRA are often viewed as going hand-in-hand, as the former forces banks to report their lending practices and the latter articulates the standards by which banks are to manage their lending. These institutional changes are considered to be among the most important federal regulations on banking since the 1930 s. $^{3}$

The CRA stipulates that lenders (1) serve the local communities in which they do business, and (2) serve those communities in their entirety including low- and middle-income constituencies (Hossain, 2004). More specifically, lending institutions should provide fair access to credit and deposit services (e.g., ensure that local communities have access to local branches or automatic teller machines), afford citizens access to a public CRA record, and be involved in the local communities they are required to serve. There are a number of different federal agencies that assess bank compliance with the CRA, including the Federal Reserve Board, the Office of the Comptroller, the Federal Deposit Insurance Corporation, and the Office of Thrift Supervision. Each agency has its own separate CRA staff that examines the banks over which it has jurisdiction depending on each banks' charter. Instead of specific criteria for meeting community needs such as percentages of loans to low income consumers, or establishing offices in low income areas, CRA performance is simply rated by the examiners on a scale of $1-4$ ( 1 = outstanding, 2 = satisfactory, 3 = needs to improve, 4 = substantial noncompliance), and there are many ways including philanthropy and other activities that banks can engage in to achieve a satisfactory CRA rating. The CRA ratings are also focused on the relationship between banking establishments and their locales and so large multi-establishment banks like Bank of America or Citigroup, which have been involved in many mergers and serve many local markets, are not assessed an overall CRA rating. Rather, each establishment-level bank is rated with regard to its CRA practices. ${ }^{4}$

Adherence to CRA requirements is one of the main axes upon which banks seeking to acquire other banks are assessed. And banks vary widely on how they achieve high ratings in this realm. Most of the commentary in the summaries of bank acquisition approvals reported each quarter in the Federal Reserve Bulletin concerns how merging banks have met CRA obligations and the potential impact of the merged institution on future CRA activities. Part of the acquisition approval process is a public comment period in the course of which citizens, legislators, and other interested parties can use the public CRA data to influence the regulatorś approval decision. For example, during the acquisition of First Interstate Bank by Wells Fargo Bank, "( $\mathrm{m}$ )ore than 600 commenters (on the banks CRA performance) either opposed the proposal, requested that the Board approve the merger subject to conditions suggested by the commenter, or expressed concerns about the CRA performance record of Wells Fargo or First Interstate" (Federal Reserve, 1996, p. 82) suggesting that the intense scrutiny of CRA behavior is a potential constraint on bank acquisitions.

In another example, in 1989, the Federal Reserve Board denied an application from Continental Bank Corporation and Continental Illinois Bancorp, Inc. to acquire all of the voting shares of Grand Canyon State Bank in Scottsdale, Arizona, based on Continental's neglect of CRA (McKinley, 1994). Further, in a high profile case, the Federal Reserve Board also denied Shawmut National Corporation's application in 1993 to acquire New Dartmouth Bank. It later reversed its decision after Shawmut agreed to settle the case for \$1 million to compensate minorities for its poor CRA performance, and after it took measures to improve such performance in the future (McKinley, 1994). As these cases show, there is significant Federal scrutiny, and for banks with poor CRA performance the merger application process is likely to be cumbersome and embarrassing. Such banks

\footnotetext{
2 "Redlining" is the practice whereby lenders assess specific communities as high risk areas-historically denoted (figuratively, and, in some cases, literally) by drawing red lines around them-based on race and ethnicity.

3 Although many scholars view the CRA as largely responsible for turning America's urban crisis around (e.g., Macey and Miller, 1993; Marsico, 2005), we believe this to be a misreading of the legislative history and immediate impact of the CRA. Indeed, the effect of the CRA in the 1970s and early 1980s was minimal. Again, because the law did not spell out exactly how banks should serve their communities, banks compliance took multiple forms, and typically became involved in low-income communities through grants and charitable donations to local nonprofit organizations (i.e. they changed their behavior enough to get CRA credit), but the legislation did nothing to change the logic of their lending practices (Guthrie and McQuarrie, 2005, 2006). This is a significant point, because the CRA was specifically intended to influence the logic of the way banks conducted business. But because they could typically score sufficiently high CRA ratings by influencing communities through philanthropic action, and because urban areas were still considered high risk, banks for the most part did not change their lending practices with respect to those areas.

${ }^{4}$ By establishment, we mean each separate banking company that is registered with the government as a separate company (i.e. a separately chartered bank) and is therefore given a CRA rating. Larger banks, such as Bank of America or Citigroup are holding companies that are composed of many banking establishments. For example, within Bank of America during the period of our study are the separate legal establishments of Bank of America California, and Bank of America North Carolina.
} 
experience significant delay and expensive litigation costs as a result of the extended public comment period they go through. For those reasons, those banks are less likely to attempt acquiring other banks, and less likely to receive regulatory clearance if they initiate the process.

Thus, we hypothesize that because of this constraint, banks with low CRA ratings are less likely to acquire other firms.

Hypothesis 1a. Banks with a low CRA rating will be less likely to acquire other banks.

But the relationship between CRA rating and acquisitions is more complex than it may appear on the surface because of the ambiguity associated with the CRA criteria and examination process. This ambiguity creates a dynamic that is very much in line with the body of institutional research that suggests that regulations are often ambiguous and that firms experiment with different practices to navigate the institutional environment (Edelman, 1990, 1992). As noted, the rating process is somewhat subjective in that a numerical value is assigned by an examiner as opposed to having concrete thresholds for certain activities. John LaWare, a member of the Federal Reserve Board of Governor's commented that "CRA's inherent vagueness (is)... frustrating at times for banks," (Fettig, 1993) but that the vagueness is somewhat necessary because of the unique situations of each bank, and the communities they are in. Further, the frequency of CRA ratings by regulators is variable, and depends on bank size and prior CRA history. Examinations occur annually for large banks and banks with poor prior ratings, but only every 5 years for smaller banks and banks with outstanding prior ratings. Thus, considerable time might have elapsed since a potential acquisition target bank's last rating which creates even further uncertainty for acquisition minded bankers.

Unlike the other research on legal ambiguity (e.g. Edelman, 1992; Dobbin and Sutton, 1998) that has focused on how firms take advantage of ambiguous laws, we argue that the uncertainty created by this ambiguity would serve as a constraint on the acquisition behavior of banks with high CRA ratings. These banks would be protective of their ratings and fearful of the risk and uncertainty associated with acquiring other banks. Thus, an unintended effect of this social provision is that it is paralyzing to the well-performing banks that should benefit from their exemplary behavior. Beyond the ability to acquire other banks, there are many benefits to a high CRA rating. First, there is significant public relations value in being perceived as serving the community well. Commercial banking is a business that is closely tied to local communities and community identity (Marquis et al., 2007; Marquis and Lounsbury, 2007), and so having an image of being an upstanding citizen is an asset for a bank. Thus, banks typically publicize positive CRA ratings in press releases (e.g. see US Bank, 2005: "US Bank Receives 'Outstanding' CRA Rating for Its Efforts in Greater Cincinnati”). The disciplining value of public perception of bank's community performance is actually the main reason why regulators made these ratings publicly available starting in 1990 (Fettig, 1993). There is also evidence that positive perceptions of consumers translate into financial performance for banks. For example, Simpson and Kohers (2002) found that there is a positive relationship between CRA performance and the financial performance of banks. And Johnson and Sarkar (1996) found that higher levels of CRA protests during acquisition hearings led to declines in banks' stock prices. CRA ratings are also used by socially responsible investment rating firms such as KLD Research and Analytics to determine if certain firms should be part of social investment funds. Because of the importance of a high rating to well performing banks and ambiguity and uncertainty associated with CRA ratings and the rating process, we believe that firms with a high CRA rating will also be less likely to acquire other firms.

Hypothesis 1b. Banks with a high CRA rating will be less likely to acquire other banks.

Thus, if the CRA ratings constrain the acquisition behavior of both the higher and lower performing banks, the former because of the risks associated with the uncertainty of target banks' true community focus, and the later because they would be unable to pass federal muster; this suggests that banks with a moderate CRA rating would be the ones more likely to acquire other banks. These firms would be able to pass the federal review of their community activities, but their ratings would not be so high as to make them fearful of jeopardizing their rating and thus shun acquisition opportunities. In a sense, because their risk is lower, the ambiguity surrounding a target's CRA rating matters less for these organizations.

Hypothesis 1c. Banks with a moderate CRA rating will be more likely to acquire other banks.

The hypotheses above suggest the federal enforcement of CRA activities has both intended and unintended consequences. While low performing CRA banks' acquisition activities are constrained, because of the ambiguity of the system, so are those of the high performing banks.

\subsection{How and why states help banks meet federal CRA requirements}

We argue that this ambiguity not only serves as a constraint; consistent with the organizational theory discussed above, this ambiguity also creates an opportunity for interested actors. In this case, not only banks but states also have an interest in aiding consolidation within their borders because larger and more powerful banks are believed to serve the economic interests of the states better. Additionally, states are also interested in preventing a social regulatory provision putting a constraint on the best performing socially-oriented banks.

The legislation that would enable states to help banks address their federal CRA ratings, and reduce acquisition-related uncertainty, was passed in 1986 as part of a major overhaul of the federal tax code. The Tax Reform Act of 1986 included a small provision that would have major implications for the development of low-income housing, while producing a windfall 
for corporations and especially banks. Congress passed the Low-Income Housing Tax Credit (LIHTC) as part of an effort to close the "passive loss" loophole - established in the Economic Recovery Act (ERA) of 1981 - that had become an extremely lucrative tax shelter for wealthy individuals. Congress decided to close the passive loss loophole but in its place leave a tax credit that would give individuals incentives to invest in low-income real estate without the incentive of driving property values down (which was central to the passive loss provision of ERA 1981).

An unintended consequence of the LIHTC was that, although the tax break was intended for individuals, it could be bought by corporations, which still had access to passive loss depreciation write-offs for corporate assets. Low-income housing could thus be counted as a corporate asset, which meant that corporations could receive both the tax credits and a tax write off against the future depreciation of low-income property. ${ }^{5}$

As noted earlier, states control the level of activity in the market for tax credits within their borders, and there is evidence that this is one of the hidden mechanisms states use to help banks address CRA concerns and thereby consolidate and retain capital. Although the LIHTC is a credit against federal taxes, use of the credits plays out at the state level in the form of their distribution by state housing agencies to developers based on a point system that reflects the priorities of the state government. The amount of credits to which a state has access depends on the population; the IRS allocates tax credits to the states at a rate of $\$ 1.80$ per person. Yet, benefits to both states and banks notwithstanding, states vary considerably in how actively they pursue the creation of a LIHTC sector. For example, the top states in LIHTC production per capita (Delaware, Louisiana, Missouri, and Texas) facilitated the production of three times as many units as the bottom producers (Nebraska, Connecticut, Alabama, and New Hampshire).

More importantly, although the LIHTC is a federal provision, individual states approached this institutional opportunity in different ways. There are no federal guidelines for how to handle the distribution of the units or how to facilitate the development of the complex public-private partnerships that these LIHTC deals require. While in most states, the state housing and community affairs department handles the allocation of LIHTCs, how actively they work with corporations, banks, municipalities, and neighborhood organizations varies considerably across states. For example, in the state of Ohio, the Ohio Department of Development works very closely with local governments (like the City of Cleveland), local nonprofit organizations, local corporations, and developers to cultivate the types of deals that are most attractive to each of these players. The ODD selects and approves the development deals that will be allocated LIHTC, but it is the facilitating role that the state agency plays that is so important in promoting the use of LIHTCs within the state. While the ODD serves many functions, the Community Action Agency within the ODD is a large office with many employees devoted solely to facilitating LIHTC development deals. In contrast, the Washington State Department of Community and Economic Development is focused on many different aspects of community development, devoting only a small amount of staff and time to facilitating LIHTC deals (Guthrie and McQuarrie, 2007).

In terms of the credits themselves, LIHTCs grant corporations and banks a dollar-for-dollar credit against tax liability as well as a "passive-loss" write-off against the future book-value depreciation of low-income property. Tax credits, much rarer and more lucrative than standard tax deductions, are subtracted directly from the amount of tax a corporation owes. For example, a bank that owes $\$ 100,000$ in taxes after taking all the typical corporate deductions from earnings, but also holds $\$ 100,000$ in LITHCs, has a tax liability for the year of $\$ 0$. Moreover, because the LIHTCs represent a physical asset, the bank is also able to deduct depreciation expenses from its income, yielding an additional financial benefit. In other words, through the LIHTC, corporations and banks get an exceedingly beneficial tax deal and also become hidden "investors" in low-income housing. Since 1986, the LIHTC has become the primary driver behind the flow of resources into inner-city housing project development, accounting for more than five billion dollars in corporate investment (Guthrie and McQuarrie, 2005).

How is all this related to banks and their CRA responsibilities? The financial benefits attached to buying the credits make participation in the LIHTC program a relatively simple calculus for corporations, and these same double-dip benefits (credit + passive loss write-off) make the program appealing to banks. ${ }^{6}$ But there is another important benefit for banks. The purchase of LIHTCs has become yet another way in which banks can get credit for servicing underserved communities and thus improve their CRA ratings without changing their lending practices (i.e., buying credits but not actually lending or issuing mortgages). Suggesting that the LIHTC has become legitimized as a way to achieve CRA credit, recent articles in Federal Reserve publications that describe how banks can participate in LIHTCs in a way that maximizes their CRA credit conclude that "the LowIncome Housing Tax Credit has proven to be an excellent investment for banks, both from a CRA and financial perspective" (Such, 2002, p. 5). LIHTCs are a significantly better deal than community-focused philanthropic donations (the primary way banks boosted CRA ratings in the late 1970s and 1980s) that only reduce taxable income by the amount of the philanthropic gift.

\footnotetext{
${ }^{5}$ This institutional innovation of using LIHTCs for corporations was first realized in 1986 by Joe Hagan of the Ohio State Housing Finance Agency and Jim Rouse of the Enterprise Foundation, both of whom would become key players in the institutionalization of this practice on a national scale (Guthrie and McQuarrie, 2005). Today, the use of LIHTCs by corporations and banks entails a complex accounting procedure that requires a variety of organizations working together to realize the double tax break. Instead of paying taxes, corporations and banks use the would-be tax dollars to purchase tax credits from a syndicator such as the National Equity Fund (NEF) or Enterprise Social Investment Corporation (ESIC), intermediary organizations that emerged in the 1980s to manage book-value tax credits they receive from the state and sell to corporations. NEF and ESIC were the earliest models of these organizations; today, most large banks provide similar services in-house.

${ }^{6}$ There are additional benefits to the LIHTC beyond the double tax break. Syndicators such as NEF often transfer the credits to corporations at a discount amounting to as much as $20 \%$ of the credits' face value, enabling a corporation to buy, for example, $\$ 1,000,000$ worth of credits for only $\$ 800,000$. Moreover, the flow of resources across the system is highly liquid because LIHTCs can be resold on the secondary market as mortgage-backed securities. Fannie Mae has become the largest holder of LIHTCs in the country through this secondary market.
} 
Although the connection between the CRA and LIHTC is little known beyond banking circles and might seem like abstract tax accounting, it is acknowledged in merger approval processes. For example, the Federal Reserve Board legal order that granted final approval for Charlotte, NC-based Bank of America's acquisition of Boston's Fleet Bank noted a number of LIHTC projects that were used to satisfy the CRA "investment test" (Federal Reserve, 2004). Nor was this an isolated instance. Bank of America, one of the nation's largest investors in the LIHTC market in recent years, engages in LIHTC activity in areas where it has acquisition-related CRA obligations (Affordable Housing, 2009). Bank of America has grown from a small North Carolina bank into the second largest bank in the United States, mainly through acquisitions made in the 1990s. It also owns the oldest bank-owned community development corporation in the country (founded in 1977). In 1999, Bank of America pledged $\$ 750$ billion over a 10-year period to community development initiatives (Bank of America, 2004), the vast majority in low-income urban areas, the very areas banks had systematically disregarded in the 1970 s. (The original pledge was $\$ 350$ billion over a 10-year period beginning in 1999; the figure was expanded to $\$ 750$ billion in 2004.) Fig. 1 shows the greater part of these resources, nearly $80 \%$ or more than $\$ 86$ billion in the first 5 years, to have gone to affordable housing.

Although largely hidden from public view, LIHTCs are among the most attractive tax mechanisms available to banks, providing a lucrative, low-risk way of serving low-income communities and thus collecting CRA credit while simultaneously facilitating the further consolidation of the US banking industry. In states with more active LIHTC regimes, there is less CRA uncertainty and risk to banks when acquiring because of the additional mechanism to fulfill CRA obligations. Thus, although states might create a market for them primarily to build low-income housing, LIHTCs also serve to retain and consolidate capital inasmuch as banks seeking acquisition opportunities can solve the problem of finding a viable acquisition target and gaining CRA credit (given a healthy market for LIHTCs) and at the same time secure lucrative tax breaks. In other words, states active in creating a market for LIHTCs are also creating incentives for banks to pursue acquisitions within their borders.

Hypothesis 2a. As state activism in the creation of a market for LIHTCs increases, so should the likelihood of banks' acquisitions within that state also increase.

If this assessment is correct, the obverse should also be true: banks headquartered in states weak in the creation of LIHTC markets should be more likely to seek acquisition targets outside of those states.

Hypothesis 2b. As state activism in the creation of a market for LIHTCs decreases, banks headquartered within that state will seek acquisitions outside of the state.

\section{Data and methods}

We test our predictions on all commercial banks in the 48 contiguous United States that received a CRA rating between 1990 and $2000 .^{7}$ The resulting database has 91,905 bank-year observations across the approximately 13,000 banks that existed during this period. CRA performance data became publicly available in 1990, and we assembled annual data on CRA performance from 1990 until 2000 from the CRA rating database of the Financial Institutions Examination Council (FFIEC) (http:// www.ffiec.gov/cracf/crarating/Rtg_spec.cfm). This year is an appropriate starting point because, although originally passed in 1986, the LIHTC was renewed and given semi-permanent status in 1989. The first year of operation under this semi-permanent status was 1990. The CRA ratings we use are for each bank that had a separate charter; our definition of a bank as a separately chartered institution is consistent with prior work in economics that studies bank acquisitions (Rhoades, 2000; Wheelock and Wilson, 2001). Because there frequently is more than one separately chartered bank within a single bank holding company, other studies of bank mergers have grouped all chartered banks in the same holding company within each state (Stiroh and Strahan, 2003). We are however constrained by the fact that CRA ratings are given to each separately chartered entity. As a check however, we ran models without the CRA variable and grouped all organizations within each holding company and obtained consistent results for our other hypothesized variables (results available by request).

We use for our dependent variable counts of the total numbers of in-state acquisitions and out-of-state acquisitions pursued by that bank during a given year. These data are from both the Commercial Bank and Bank Holding Company Merger databases maintained by the Chicago Federal Reserve (http://www.chicagofed.org/economic_research_and_data/commercial_bank_data.cfm). Our two primary independent variables are a bank's CRA rating and state-level low income housing development credits issued by a state. We ran models with three different dummy variables to show the varying effects of different CRA levels. High CRA rating was assigned to firms with a CRA rating of 1 (outstanding); moderate CRA rating to indicate CRA rating of 2 (satisfactory); and low CRA rating firms with ratings of 3 or 4 (needs to improve and substantial noncompliance). We gauge state activism in the area of low-income housing development in terms of the total number of LIHTC credits a state authorized in each year. We collected the LIHTC data from the US Bureau of Census and The Danter Company, a private market feasibility company for the real estate industry (www.danter.com). We use the natural log transformation of this variable to reduce the skewed effect of outliers on the models.

\footnotetext{
${ }^{7}$ All banks that are larger than 250 million in assets or part of a bank holding company that has cumulatively over 250 million in assets are required to submit to CRA examination.
} 


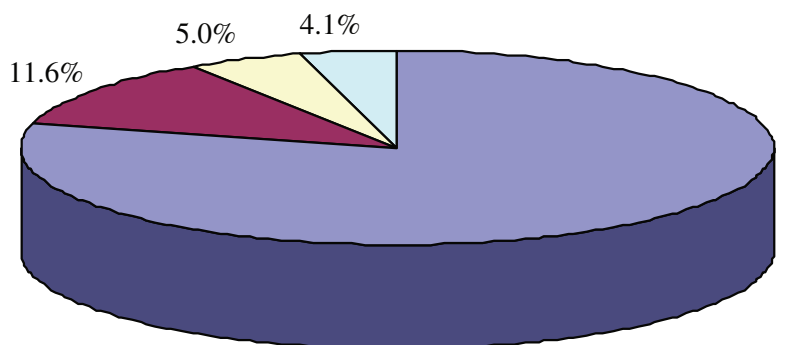

$79.3 \%$

$\square$ Affordable Housing

$\square$ Consumer $\square$ Small Business

$\square$ Economic Development

Fig. 1. Bank of America's lending and investment in community economic development, 1999-2004.

We included a number of control variables in our analyses to account for characteristics of banks and their economic and institutional environment that may make acquisitions more or less likely. The two most important bank characteristics relating to acquisitions are bank performance and bank size (Rhoades, 2000; Stiroh and Strahan, 2003). We operationalized performance as return on equity ( $R O E$ ) which is the ratio of income to equity and bank size as each bank's total assets. We also included a variable to indicate if a bank's headquarters was in an urban area (MSA), as prior research has shown urban areas to be more fruitful acquisition markets (Pillof, 2004), and further, urban banks may be less community-oriented, which would influence their CRA focus. These variables are from the Commercial Bank and Bank Holding Company databases maintained by the Chicago Federal Reserve and the financial variables are lagged 1 year. To account for state-level economic conditions that might influence acquisition activity, we included for each state per capita income, total population ${ }^{8}$ (logged because of extreme values), percentage of the population that lived in urbanized areas, number of banks and average size of banks (logged because of extreme values). These variables were obtained from the US Census and banking databases mentioned above. We also created a dummy variable if the year was after 1994 to control for effects of the merger wave that occurred from 1994 to 2000 (Marquis and Lounsbury, 2007). Other aspects of state-level legal environments may also influence acquisitions, so we included variables for whether a state permits interstate banking and has a unit banking law (which limits banks to one location). The interstate banking law variable was included only in models that predicted in-state acquisitions (because if bank is $_{i}$ acquiring an out-of-state bank in state ${ }_{j}$, state ${ }_{j}$, by definition, allows interstate banking). These data on state laws were assembled from Conference of State Bank Supervisors biannual publication A Profile of State-Chartered Banking.

Our dependent variables are counts of acquisitions by each bank in a given year and we considered two primary ways of analyzing these data. The traditional method, Poisson regression, is appropriate when the mean and variance of the dependent variable are similar. But when the variance is greater than the mean (the case here) the data are considered over-dispersed and negative binomial regression is the most appropriate specification. A further issue with these data is that not all observations are independent as we have multiple observations for many banks in the study period. To correct for this, we use a random effects panel model that accounts for situations in which there are multiple observations per firm over time (xtnbreg command in STATA). The general model we use to analyze the associations among these variables takes the form of a random effects model for the determinants of bank acquisitions by bank $i$ within and outside of the state in which a given bank, $i$, is located that takes the form of:

$$
Y_{i j t}=\alpha+\beta_{1}(\mathrm{CRA})_{i t}+\beta_{2}(\mathrm{LIHTC})_{j t}+\gamma Z_{i t}+\delta_{i}+\lambda_{t}+\varepsilon_{i t}
$$

where $Y_{i j t}$ represents the number of acquisitions for bank $i$ in state $j$ at time $t, \alpha$ is an intercept, (CRA) is a dummy variable indicating the CRA rating of bank $i$ at time $t$, (LIHTC) $)_{j t}$ represents the LITHC environment of state $j$ at time $t$. $\beta_{1}$ represents the effect of a bank's CRA rating on the outcome variables and $\beta_{2}$ represents the effect of states' LIHTC promotion on the outcome variables, $Z_{i t}$ is a vector of measurable bank-level variables for bank $i$ at time $t, \gamma$ is a vector of regression coefficients corresponding to the variables in vector $Z, \delta_{i}$ represents random effects of bank-level heterogeneity, $\lambda_{t}$ represents unobserved time-based heterogeneity (year effects), and $\varepsilon_{i t}$ is a time-varying error term. Congruent with the assumptions of random effects models, we assume that the unobserved effects are uncorrelated with $Z_{i}$ and $\varepsilon_{i}$ (Hausman, 1978). These models are estimated in a GLS framework using the negative binomial regression program in Stata 9. Given the possibility of unobserved firm-level determinants of these outcomes, it could be argued that a fixed effects model would be more appropriate, but because some organizations are in the dataset for only 1 year it is not possible to use fixed effects as there would be no variance in the panel for these cases.

\footnotetext{
${ }^{8}$ Observing a high correlation between state population and LIHTC, we ran the existing models without state population and obtained consistent results throughout and even stronger results for the LIHTC variable. To be conservative, we report models that include state population as a control.
} 
To estimate a potential effect of multicolinearity, we calculated variance inflation factors (VIF) and the average VIF of the key variables was under 3 , and no single variable was above 10 , which is the standard cutoff signaling a multicollinearity problem.

\section{Results}

Table 1 presents the descriptive statistics and correlations. The correlations between state LIHTC activity and CRA ratings are low: -.068 for high rating banks, and .048 and .045 for moderate and low CRA ratings, respectively. Tables 2 and 3 present the regression models for bank acquisitions within state of headquarters and outside state of headquarters, respectively. The latter tables are similar in format. Model I has all control variables. Model II adds the LIHTC variable, models III and IV present the low CRA analyses, with and without the LIHTC variable, models V and VI present the high CRA analyses and models VII and VIII the moderate CRA analyses. In addition, while we base our interpretations on the above noted models, for informational purposes, we added model VIII to test the effects of moderate and low CRA ratings relative to high CRA ratings (the referent dummy variable).

Hypothesis 1a considered how low CRA banks would be less likely to acquire others and results are mixed in support of this hypothesis. While it does appear that low CRA firms are constrained in making within-state acquisitions (Model III of Table 2), this variable, while negative is not statistically significant for outside state acquisitions. Turning to the high CRA rated banks, results strongly support our contention in Hypothesis 1b that these firms are constrained by their high rating and are therefore less likely to acquire other firms. In both the within state and outside state analyses, this variable is strongly significant in the negative direction. The -0.125 coefficient in the within state analyses can be interpreted as follows: banks with high CRA ratings are $12 \%$ less likely than other firms to make acquisitions within their focal state (1 - exp $(-0.125)=0.12)$. This effect is even more pronounced for outside-state acquisitions as high CRA firms are $46 \%$ less likely than other banks to make acquisitions across state lines $(1-\exp (-0.617)=0.46)$. In assessing Hypothesis $1 c$, that banks with moderate CRA ratings are more likely to acquire other banks, note in both Tables 2 and 3 that the variable that captures moderate CRA rating is strongly significant, supporting our hypotheses and further supporting our case that CRA rating serves as a constraint on acquisitions. These CRA results support our hypotheses that both high and low rated banks would be constrained in their acquisitions.

In Model VIII of both Tables 2 and 3 we present models for informational purposes where we include the variables for both moderate and low CRA rating, thus, high CRA rating is the reference group. As the results show, banks with moderate CRA ratings perform higher levels of acquisitions than banks with high CRA ratings, both within and out-of-state, as we hypothesized. However, while Table 2 shows that banks with low CRA ratings are significantly less likely ( $40 \%=1-$ exp $(-0.507)=0.40)$ to perform in-state acquisitions than banks with high CRA ratings, the corresponding model in Table 3 shows that the same is not true of out-of-state acquisitions. Here the effect is not significant. In the discussion, we discuss how this difference in effects across types of acquisitions of low versus high CRA rate banks may be a result of different types of uncertainty and risk that high and low CRA rated banks face when contemplating within state and out of state acquisitions.

Hypothesis 2a, which predicts that a state's level of activism in creating an LIHTC market increases the likelihood of a bank acquisition within the state, is strongly supported by the results reported in Table 2. Even controlling for many other organizational and state-level controls, the more active a state is in LIHTCs, the more likely its banks are to acquire other banks within the state. The 0.185 coefficient of the LIHTC variable on count of within state acquisitions can be interpreted as follows: for every one unit change in the natural log of a state's LIHTC spending, the likelihood of acquiring a bank in the same state increases by $20 \%(\exp (0.185)=1.20)$. This supports our contention that states with activist LIHTC programs that help their banks satisfy CRA requirements are more likely to be effective at retaining capital. Hypothesis $2 \mathrm{~b}$, which predicts that banks in states that do not actively pursue a market for LIHTCs are more likely to pursue bank acquisitions outside of those states, is strongly supported by the results reported in Table 3. These results essentially mirror those reported in Table 2, suggesting a negative relationship between LIHTC and out-of-state acquisitions. The -0.409 coefficient of the LIHTC variable on count of acquisitions outside of the state can be interpreted as follows: for every one unit decrease in the natural $\log$ of a state's LIHTC spending, the likelihood of acquiring a bank out of the state increases by $34 \%(1-\exp (-0.409)=0.34)$. This suggests that, even controlling for many other organizational and state-level variables, the less active a state is in LIHTCs, the more likely its banks look elsewhere for acquisitions.

Results of some control variables in the tables are also quite interesting. First, contrary to some economic research (Stiroh and Strahan, 2003), it appears that bank size influences to a much greater degree than bank performance which banks acquire other banks. As would be expected based on prior analyses of changes following deregulation in the financial services industry (Haveman, 1993), larger banks are more likely to acquire both in-state and out-of-state firms. Bank performance (ROE), on the other hand, is negatively associated with acquisition activity. This, however, may simply indicate a causal relationship in the opposite direction. Banks consolidating may have initially lower performance in terms of ROE. (Those banks may end up on average with proportionally more equity in the denominator than additional income in the numerator.)

States with interstate banking laws tend to see fewer in-state mergers, as banks in those states presumably have more opportunities available to them out of state. Further, the merger wave variable that captured the period following federal 
Table 1

Descriptive statistics and correlations.

\begin{tabular}{|c|c|c|c|c|c|c|c|c|c|c|c|c|c|c|c|c|c|c|c|}
\hline & & Mean & S.D. & 1 & 2 & 3 & 4 & 5 & 6 & 7 & 8 & 9 & 10 & 11 & 12 & 13 & 14 & & \\
\hline 1 & Interstate acquisitions & 0.005 & 0.233 & & & & & & & & & & & & & & & & \\
\hline 2 & Instate acquisitions & 0.033 & 0.262 & 0.018 & & & & & & & & & & & & & & & \\
\hline 3 & High CRA rating & 0.188 & 0.391 & 0.013 & 0.023 & & & & & & & & & & & & & & \\
\hline 4 & Moderate CRA rating & 0.785 & 0.411 & -0.011 & -0.017 & -0.921 & & & & & & & & & & & & & \\
\hline 5 & Low CRA rating & 0.026 & 0.161 & -0.003 & -0.012 & -0.080 & -0.315 & & & & & & & & & & & & \\
\hline 6 & LIHTC credits & 7.480 & 0.957 & -0.003 & 0.027 & -0.068 & 0.048 & 0.045 & & & & & & & & & & & \\
\hline 7 & ROE & 0.942 & 2.705 & 0.001 & 0.000 & 0.004 & -0.013 & 0.023 & 0.010 & & & & & & & & & & \\
\hline 8 & Total assets & 11.22 & 1.296 & 0.080 & 0.204 & 0.175 & -0.150 & -0.043 & 0.075 & 0.015 & & & & & & & & & \\
\hline 9 & HQ in MSA & 0.452 & 0.498 & 0.017 & 0.065 & -0.009 & -0.021 & 0.075 & 0.211 & 0.025 & 0.376 & & & & & & & & \\
\hline 10 & Interstate banking law & 0.990 & 0.099 & 0.002 & 0.000 & 0.022 & -0.015 & -0.014 & 0.102 & -0.006 & 0.080 & 0.056 & & & & & & & \\
\hline 11 & Unit banking law & 0.003 & 0.051 & -0.001 & 0.000 & -0.013 & -0.002 & 0.037 & -0.043 & 0.008 & -0.035 & 0.001 & 0.005 & & & & & & \\
\hline 12 & Per capita income & 26,608 & 3512 & 0.001 & 0.001 & 0.015 & -0.016 & 0.003 & 0.131 & -0.007 & 0.222 & 0.277 & 0.091 & -0.018 & & & & & \\
\hline 13 & State population & 15.54 & 0.889 & 0.001 & 0.024 & -0.052 & 0.036 & 0.035 & 0.863 & 0.005 & 0.172 & 0.295 & 0.129 & -0.018 & 0.404 & & & & \\
\hline 14 & Urban Population (\%) & 0.722 & 0.121 & -0.009 & 0.019 & -0.050 & 0.025 & 0.059 & 0.562 & 0.011 & 0.150 & 0.354 & 0.078 & 0.014 & 0.677 & 0.715 & & & \\
\hline 15 & State banking assets & 12.56 & 0.980 & 0.025 & 0.029 & -0.003 & -0.008 & 0.027 & 0.323 & 0.007 & 0.408 & 0.363 & 0.144 & -0.048 & 0.531 & 0.511 & 0.464 & & \\
\hline 16 & Numb. banks in state & 671.5 & 442.3 & -0.014 & -0.010 & -0.049 & 0.041 & 0.016 & 0.538 & 0.002 & -0.184 & -0.018 & -0.010 & 0.005 & 0.125 & 0.508 & 0.406 & -0.234 & \\
\hline 17 & Merger wave & 0.594 & 0.491 & 0.014 & -0.021 & 0.109 & -0.057 & -0.122 & -0.163 & -0.023 & 0.142 & 0.006 & 0.121 & -0.061 & 0.329 & 0.046 & 0.063 & 0.171 & -0.107 \\
\hline
\end{tabular}


Table 2

Random effects negative binomial models of banks acquiring within state of headquarters (DV: count of acquisitions).

\begin{tabular}{|c|c|c|c|c|c|c|c|c|c|}
\hline & Model I & Model II & Model III & Model IV & Model V & Model VI & Model VII & Model VII & Model VIII \\
\hline Low CRA rating $(0 / 1)$ & & & $\begin{array}{l}-0.62899^{* *} \\
(3.36)\end{array}$ & $\begin{array}{l}-0.62241^{* *} \\
(3.32)\end{array}$ & & & & & $\begin{array}{l}-0.5073^{* *} \\
(2.63)\end{array}$ \\
\hline High CRA rating $(0 / 1)$ & & & & & $\begin{array}{l}-0.1245^{*} \\
(2.28)\end{array}$ & $\begin{array}{l}-0.12718^{*} \\
(2.33)\end{array}$ & & & \\
\hline Moderate CRA rating $(0 / 1)$ & & & & & & & $\begin{array}{l}0.17801^{* *} \\
(3.38)\end{array}$ & $\begin{array}{l}0.17984^{* *} \\
(3.41)\end{array}$ & $\begin{array}{l}0.13883^{*} \\
(2.54)\end{array}$ \\
\hline $\begin{array}{l}\text { Ln (State Low Income } \\
\text { Housing Tax Credit) }\end{array}$ & & $\begin{array}{l}0.18486^{* *} \\
(3.23)\end{array}$ & & $\begin{array}{l}0.18214^{* *} \\
(3.19)\end{array}$ & & $\begin{array}{l}0.18692^{* *} \\
(3.27)\end{array}$ & & $\begin{array}{l}0.18688^{* *} \\
(3.27)\end{array}$ & $\begin{array}{l}0.18427^{*, * *} \\
(057)\end{array}$ \\
\hline ROE & $\begin{array}{l}-0.02943^{* *} \\
(2.87)\end{array}$ & $\begin{array}{l}-0.02934^{* *} \\
(2.84)\end{array}$ & $\begin{array}{l}-0.02933^{* * *} \\
(2.84)\end{array}$ & $\begin{array}{l}-0.0292^{* *} \\
(2.81)\end{array}$ & $\begin{array}{l}-0.02929^{* *} \\
(2.86)\end{array}$ & $\begin{array}{l}-0.0292^{* *} \\
(2.83)\end{array}$ & $\begin{array}{l}-0.0292^{* *} \\
(2.85)\end{array}$ & $\begin{array}{l}-0.0291^{* *} \\
(2.82)\end{array}$ & $\begin{array}{l}-0.0291^{* *} \\
(3.23)\end{array}$ \\
\hline Ln (total assets) & $\begin{array}{l}0.96549^{* *} \\
(41.42)\end{array}$ & $\begin{array}{l}0.96534^{* *} \\
(41.34)\end{array}$ & $\begin{array}{l}0.9622^{* *} \\
(41.24)\end{array}$ & $\begin{array}{l}0.9621^{* *} \\
(41.17)\end{array}$ & $\begin{array}{l}0.97333^{* *} \\
(41.28)\end{array}$ & $\begin{array}{l}0.97339^{* *} \\
(41.21)\end{array}$ & $\begin{array}{l}0.97551^{* *} \\
(41.46)\end{array}$ & $\begin{array}{l}0.97552^{* * *} \\
(41.39)\end{array}$ & $\begin{array}{l}0.9707^{* * *} \\
(41.08)\end{array}$ \\
\hline HQ in MSA $(0 / 1)$ & $\begin{array}{l}-0.14403^{*} \\
(2.24)\end{array}$ & $\begin{array}{l}-0.14458^{*} \\
(2.25)\end{array}$ & $\begin{array}{l}-0.13099^{*} \\
(2.04)\end{array}$ & $\begin{array}{l}-0.13173^{*} \\
(2.05)\end{array}$ & $\begin{array}{l}-0.14872^{*} \\
(2.31)\end{array}$ & $\begin{array}{l}-0.14946^{*} \\
(2.33)\end{array}$ & $\begin{array}{l}-0.14618^{*} \\
(2.28)\end{array}$ & $\begin{array}{l}-0.1469^{*} \\
(2.29)\end{array}$ & $\begin{array}{l}-0.1365^{*} \\
(2.12)\end{array}$ \\
\hline $\begin{array}{l}\text { State unit banking law } \\
(0 / 1)\end{array}$ & $\begin{array}{l}0.12699 \\
(0.33)\end{array}$ & $\begin{array}{l}0.2691 \\
(0.69)\end{array}$ & $\begin{array}{l}0.14406 \\
(0.37)\end{array}$ & $\begin{array}{l}0.28404 \\
(0.73)\end{array}$ & $\begin{array}{l}0.10107 \\
(0.26)\end{array}$ & $\begin{array}{l}0.24443 \\
(0.63)\end{array}$ & $\begin{array}{l}0.09548 \\
(0.25)\end{array}$ & $\begin{array}{l}0.23918 \\
(0.62)\end{array}$ & $\begin{array}{l}0.23918 \\
(0.62)\end{array}$ \\
\hline $\begin{array}{l}\text { State interstate banking law } \\
(0 / 1)\end{array}$ & $\begin{array}{l}-0.59023^{* *} \\
(2.90)\end{array}$ & $\begin{array}{l}-0.6226^{* *} \\
(3.05)\end{array}$ & $\begin{array}{l}-0.59713^{* * *} \\
(2.93)\end{array}$ & $\begin{array}{l}-0.62918^{* *} \\
(3.08)\end{array}$ & $\begin{array}{l}-0.57875^{* *} \\
(2.84)\end{array}$ & $\begin{array}{l}-0.61158^{* * *} \\
(2.99)\end{array}$ & $\begin{array}{l}-0.57613^{* *} \\
(2.82)\end{array}$ & $\begin{array}{l}-0.60926^{* *} \\
(2.98)\end{array}$ & $\begin{array}{l}-0.6017^{* * *} \\
(3.02)\end{array}$ \\
\hline $\begin{array}{l}\text { State per capita income } \\
\quad(2001 \$ \text { s) }\end{array}$ & $\begin{array}{l}-0.00007^{* *} \\
(5.72)\end{array}$ & $\begin{array}{l}-0.00005^{* *} \\
(4.25)\end{array}$ & $\begin{array}{l}-0.00007^{* *} \\
(5.75)\end{array}$ & $\begin{array}{l}-0.00005^{* *} \\
(4.30)\end{array}$ & $\begin{array}{l}-0.00007^{* *} \\
(5.81)\end{array}$ & $\begin{array}{l}-0.00005^{* *} \\
(4.32)\end{array}$ & $\begin{array}{l}-0.00007^{* *} \\
(5.85)\end{array}$ & $\begin{array}{l}-0.00005^{* *} \\
(4.36)\end{array}$ & $\begin{array}{l}-0.00005^{* *} \\
(4.37)\end{array}$ \\
\hline Ln (total state population) & $\begin{array}{l}0.10176+ \\
(1.76)\end{array}$ & $\begin{array}{l}-0.06593 \\
(0.85)\end{array}$ & $\begin{array}{l}0.09953+ \\
(1.72)\end{array}$ & $\begin{array}{l}-0.06568 \\
(0.85)\end{array}$ & $\begin{array}{l}0.09813+ \\
(1.70)\end{array}$ & $\begin{array}{l}-0.07154 \\
(0.92)\end{array}$ & $\begin{array}{l}0.09579+ \\
(1.66)\end{array}$ & $\begin{array}{l}-0.07385 \\
(0.95)\end{array}$ & $\begin{array}{l}-0.0725 \\
(0.92)\end{array}$ \\
\hline $\begin{array}{l}\text { Percent state population in } \\
\text { urban areas }\end{array}$ & $\begin{array}{l}2.116^{* *} \\
(5.24)\end{array}$ & $\begin{array}{l}1.98237^{* *} \\
(4.86)\end{array}$ & $\begin{array}{l}2.14973^{* *} \\
(5.32)\end{array}$ & $\begin{array}{l}2.01842^{* *} \\
(4.95)\end{array}$ & $\begin{array}{l}2.12352^{* *} \\
(5.26)\end{array}$ & $\begin{array}{l}1.98847^{* *} \\
(4.88)\end{array}$ & $\begin{array}{l}2.13802^{* * *} \\
(5.29)\end{array}$ & $\begin{array}{l}2.00325^{* *} \\
(4.92)\end{array}$ & $\begin{array}{l}2.0261^{* *} \\
(4.97)\end{array}$ \\
\hline Ln (state banking assets) & $\begin{array}{l}-0.39837^{* *} \\
(8.70)\end{array}$ & $\begin{array}{l}-0.40227^{* *} \\
(8.78)\end{array}$ & $\begin{array}{l}-0.39548^{* * *} \\
(8.63)\end{array}$ & $\begin{array}{l}-0.3994^{* * *} \\
(8.72)\end{array}$ & $\begin{array}{l}-0.40159^{* *} \\
(8.77)\end{array}$ & $\begin{array}{l}-0.40553^{* *} \\
(8.86)\end{array}$ & $\begin{array}{l}-0.40195^{* *} \\
(8.79)\end{array}$ & $\begin{array}{l}-0.40583^{* *} \\
(8.87)\end{array}$ & $\begin{array}{l}-0.4028^{* *} \\
(8.80)\end{array}$ \\
\hline Number of banks in state & $\begin{array}{l}-0.00012 \\
(1.31)\end{array}$ & $\begin{array}{l}-0.00017+ \\
(1.80)\end{array}$ & $\begin{array}{l}-0.00012 \\
(1.31)\end{array}$ & $\begin{array}{l}-0.00017+ \\
(1.80)\end{array}$ & $\begin{array}{l}-0.00011 \\
(1.24)\end{array}$ & $\begin{array}{l}-0.00016+ \\
(1.74)\end{array}$ & $\begin{array}{l}-0.00011 \\
(1.21)\end{array}$ & $\begin{array}{l}-0.00016+ \\
(1.71)\end{array}$ & $\begin{array}{l}-0.00016+ \\
(1.72)\end{array}$ \\
\hline Merger wave $(0 / 1)$ & $\begin{array}{l}-0.65619^{* *} \\
(14.04)\end{array}$ & $\begin{array}{l}-0.61^{* *} \\
(12.43)\end{array}$ & $\begin{array}{l}-0.67052^{* *} \\
(14.31)\end{array}$ & $\begin{array}{l}-0.62475^{* *} \\
(12.71)\end{array}$ & $\begin{array}{l}-0.64644^{* *} \\
(13.77)\end{array}$ & $\begin{array}{l}-0.59952^{* *} \\
(12.16)\end{array}$ & $\begin{array}{l}-0.64728^{* *} \\
(13.81)\end{array}$ & $\begin{array}{l}-0.60044^{* *} \\
(12.21)\end{array}$ & $\begin{array}{l}-0.6144^{* *} \\
(12.44)\end{array}$ \\
\hline Constant & $\begin{array}{l}-7.80881^{* *} \\
(12.11)\end{array}$ & $\begin{array}{l}-6.77327^{* *} \\
(9.42)\end{array}$ & $\begin{array}{l}-7.76602^{* *} \\
(12.04)\end{array}$ & $\begin{array}{l}-6.74514^{* *} \\
(9.38)\end{array}$ & $\begin{array}{l}-7.765^{* *} \\
(12.04)\end{array}$ & $\begin{array}{l}-6.71777^{* *} \\
(9.33)\end{array}$ & $\begin{array}{l}-7.90997^{* *} \\
(12.25)\end{array}$ & $\begin{array}{l}-6.86489^{* *} \\
(9.54)\end{array}$ & $\begin{array}{l}-6.82189^{* *} \\
(12.44)\end{array}$ \\
\hline Observations & 91918 & 91918 & 91918 & 91918 & 91918 & 91918 & 91918 & 91918 & 91918 \\
\hline Number of banks & 12936 & 12936 & 12936 & 12936 & 12936 & 12936 & 12936 & 12936 & 12936 \\
\hline Chi square & 2015.67 & 2021.12 & 2024.83 & 2030.27 & 2019.32 & 2024.81 & 2024.43 & 2029.93 & 2035.16 \\
\hline
\end{tabular}

Two-tail for controls, one-tail for hypothesized effects; Absolute value of $z$ statistics in parentheses.

* Significant at $5 \%$.

** Significant at $1 \%$.

deregulation in 1994 is also an important spur for firms to look outside, but not within, their state of headquarters for acquisition targets.

Banks from states with fewer banks and lower banking assets acquire more banks, both inside and outside the state, than banks from states with more or larger banks, which may be an indication that most acquisitions are small. There are also more acquisitions within state in states with proportionally more urban areas and lower per capita income, and by banks that are not headquartered in a MSA.

The results of our investigation into effects of the CRA ratings of individual banks and state-level investment on LIHTCs are consistent with our theory of how states help organizations address ambiguous federal regulations. CRA ratings are ambiguous and hence the highest performing firms are less likely to acquire other banks. Further, our analyses show federal and state activity around the Low-Income Housing Tax Credit to be one of the strongest predictors of bank merger activity between 1990 and 2000. Thus, some states found ways to increase bank acquisitions within their borders in the face of federal regulatory mandates that acted as a constraint on such activity.

\section{Discussion and conclusions}

After a century of progressive deregulation of banking markets, one significant remaining impediment to bank expansion is the Community Reinvestment Act (CRA), which is dependent upon how well banks serve low-income communities. A response to public umbrage over banks' unfair treatment of low-income communities, the CRA has become one of the key ways the federal government assesses whether banks are meeting their social obligations by treating all communities fairly. It has also become one of the key indices considered by the federal government in approving bank mergers; thus enforcement of this social provision relies on the degree to which the government is able to constrain banks' acquisitions.

As we have shown, CRA ratings determine to a significant degree whether banks engage in acquisitions. Public and governmental scrutiny of banks with low CRA ratings is an impediment to acquisitions, but a further unintended consequence is 
Table 3

Models of banks acquiring outside state of headquarters. (DV: count of acquisitions).

\begin{tabular}{|c|c|c|c|c|c|c|c|c|c|}
\hline & Model I & Model II & Model III & Model IV & Model V & Model VI & Model VII & Model VII & Model VIII \\
\hline Low CRA rating $(0 / 1)$ & & & $\begin{array}{l}-0.27857 \\
(0.27)\end{array}$ & $\begin{array}{l}-0.28454 \\
(0.28)\end{array}$ & & & & & $\begin{array}{l}0.201 \\
(3.40)\end{array}$ \\
\hline High CRA rating $(0 / 1)$ & & & & & $\begin{array}{l}-0.61736^{* *} \\
(3.41)\end{array}$ & $\begin{array}{l}-0.61331^{* *} \\
(3.38)\end{array}$ & & & \\
\hline Moderate CRA rating $(0 / 1)$ & & & & & & & $\begin{array}{l}0.61515^{* *} \\
(3.43)\end{array}$ & $\begin{array}{l}0.61125^{* *} \\
(3.41)\end{array}$ & $\begin{array}{l}0.616^{* *} \\
(3.40)\end{array}$ \\
\hline $\begin{array}{l}\text { Ln (State Low Income } \\
\text { Housing Tax Credit) }\end{array}$ & & $\begin{array}{l}-0.40924^{*} \\
(1.90)\end{array}$ & & $\begin{array}{l}-0.40941^{*} \\
(1.90)\end{array}$ & & $\begin{array}{l}-0.39509^{*} \\
(1.84)\end{array}$ & & $\begin{array}{l}-0.39536^{*} \\
(1.84)\end{array}$ & $\begin{array}{l}-0.39527+ \\
(1.84)\end{array}$ \\
\hline ROE & $\begin{array}{l}-0.03675 \\
(1.51)\end{array}$ & $\begin{array}{l}-0.03693 \\
(1.46)\end{array}$ & $\begin{array}{l}-0.03668 \\
(1.51)\end{array}$ & $\begin{array}{l}-0.03686 \\
(1.45)\end{array}$ & $\begin{array}{l}-0.03623 \\
(1.42)\end{array}$ & $\begin{array}{l}-0.03629 \\
(1.36)\end{array}$ & $\begin{array}{l}-0.03606 \\
(1.41)\end{array}$ & $\begin{array}{l}-0.03613 \\
(1.35)\end{array}$ & $\begin{array}{l}-0.03616 \\
(1.35)\end{array}$ \\
\hline Ln (total assets) & $\begin{array}{l}0.99508^{* *} \\
(21.07)\end{array}$ & $\begin{array}{l}0.99378^{* *} \\
(21.00)\end{array}$ & $\begin{array}{l}0.99426^{* *} \\
(21.02)\end{array}$ & $\begin{array}{l}0.99293^{* *} \\
(20.95)\end{array}$ & $\begin{array}{l}1.03633^{* *} \\
(21.36)\end{array}$ & $\begin{array}{l}1.03462^{* *} \\
(21.29)\end{array}$ & $\begin{array}{l}1.03449^{* *} \\
(21.38)\end{array}$ & $\begin{array}{l}1.03275^{* *} \\
(21.31)\end{array}$ & $\begin{array}{l}1.0335^{* *} \\
(21.25)\end{array}$ \\
\hline HQ in MSA $(0 / 1)$ & $\begin{array}{l}0.17225 \\
(0.67)\end{array}$ & $\begin{array}{l}0.18064 \\
(0.70)\end{array}$ & $\begin{array}{l}0.17443 \\
(0.68)\end{array}$ & $\begin{array}{l}0.18294 \\
(0.71)\end{array}$ & $\begin{array}{l}0.13767 \\
(0.54)\end{array}$ & $\begin{array}{l}0.14661 \\
(0.57)\end{array}$ & $\begin{array}{l}0.14258 \\
(0.56)\end{array}$ & $\begin{array}{l}0.1516 \\
(0.59)\end{array}$ & $\begin{array}{l}0.150 \\
(0.58)\end{array}$ \\
\hline $\begin{array}{l}\text { State unit banking law } \\
(0 / 1)\end{array}$ & $\begin{array}{l}-15.05432 \\
(0.5)\end{array}$ & $\begin{array}{l}-15.01773 \\
(0.8)\end{array}$ & $\begin{array}{l}-14.91063 \\
(0.1)\end{array}$ & $\begin{array}{l}-15.0036 \\
(0.2)\end{array}$ & $\begin{array}{l}-13.74874 \\
(0.7)\end{array}$ & $\begin{array}{l}-13.93426 \\
(0.6)\end{array}$ & $\begin{array}{l}-13.70265 \\
(0.9)\end{array}$ & $\begin{array}{l}-14.0133 \\
(0.0)\end{array}$ & $\begin{array}{l}-14.0402 \\
(0.0)\end{array}$ \\
\hline $\begin{array}{l}\text { State per capita income } \\
\quad(2001 \text { \$s) }\end{array}$ & $\begin{array}{l}-0.00001 \\
(0.15)\end{array}$ & $\begin{array}{l}-0.00002 \\
(0.57)\end{array}$ & $\begin{array}{l}-0.00001 \\
(0.15)\end{array}$ & $\begin{array}{l}-0.00002 \\
(0.57)\end{array}$ & $\begin{array}{l}-0.00001 \\
(0.04)\end{array}$ & $\begin{array}{l}-0.00002 \\
(0.64)\end{array}$ & $\begin{array}{l}-0.00001 \\
(0.04)\end{array}$ & $\begin{array}{l}-0.00002 \\
(0.64)\end{array}$ & $\begin{array}{l}-0.00002 \\
(0.64)\end{array}$ \\
\hline Ln (total state population) & $\begin{array}{l}-0.2056 \\
(1.55)\end{array}$ & $\begin{array}{l}0.17233 \\
(0.72)\end{array}$ & $\begin{array}{l}-0.20629 \\
(1.55)\end{array}$ & $\begin{array}{l}0.17177 \\
(0.72)\end{array}$ & $\begin{array}{l}-0.21666 \\
(1.63)\end{array}$ & $\begin{array}{l}0.14662 \\
(0.61)\end{array}$ & $\begin{array}{l}-0.21813 \\
(1.64)\end{array}$ & $\begin{array}{l}0.14539 \\
(0.61)\end{array}$ & $\begin{array}{l}0.14556 \\
(0.61)\end{array}$ \\
\hline $\begin{array}{l}\text { Percent state population in } \\
\text { urban areas }\end{array}$ & $\begin{array}{l}-0.13514 \\
(0.14)\end{array}$ & $\begin{array}{l}0.06115 \\
(0.06)\end{array}$ & $\begin{array}{l}-0.12966 \\
(0.13)\end{array}$ & $\begin{array}{l}0.06671 \\
(0.07)\end{array}$ & $\begin{array}{l}-0.28697 \\
(0.29)\end{array}$ & $\begin{array}{l}-0.0938 \\
(0.10)\end{array}$ & $\begin{array}{l}-0.27564 \\
(0.28)\end{array}$ & $\begin{array}{l}-0.08253 \\
(0.08)\end{array}$ & $\begin{array}{l}-0.08627 \\
(0.09)\end{array}$ \\
\hline Ln (state banking assets) & $\begin{array}{l}-0.33604^{* *} \\
(3.56)\end{array}$ & $\begin{array}{l}-0.33448^{* *} \\
(3.53)\end{array}$ & $\begin{array}{l}-0.33497^{* * *} \\
(3.55)\end{array}$ & $\begin{array}{l}-0.33336^{* *} \\
(3.51)\end{array}$ & $\begin{array}{l}-0.32828^{* *} \\
(3.49)\end{array}$ & $\begin{array}{l}-0.32671^{* *} \\
(3.46)\end{array}$ & $\begin{array}{l}-0.32606^{* * *} \\
(3.46)\end{array}$ & $\begin{array}{l}-0.32444^{* *} \\
(3.43)\end{array}$ & $\begin{array}{l}-0.3249^{* *} \\
(3.44)\end{array}$ \\
\hline Number of banks in state & $\begin{array}{l}-0.00083^{*} \\
(2.45)\end{array}$ & $\begin{array}{l}-0.00077^{*} \\
(2.28)\end{array}$ & $\begin{array}{l}-0.00083^{*} \\
(2.45)\end{array}$ & $\begin{array}{l}-0.00077^{*} \\
(2.27)\end{array}$ & $\begin{array}{l}-0.00081^{*} \\
(2.40)\end{array}$ & $\begin{array}{l}-0.00076^{*} \\
(2.23)\end{array}$ & $\begin{array}{l}-0.00081^{*} \\
(2.39)\end{array}$ & $\begin{array}{l}-0.00075^{*} \\
(2.22)\end{array}$ & $\begin{array}{l}-0.00075^{*} \\
(2.22)\end{array}$ \\
\hline Merger wave $(0 / 1)$ & $\begin{array}{l}1.1154^{* *} \\
(4.84)\end{array}$ & $\begin{array}{l}1.03828^{* *} \\
(4.47)\end{array}$ & $\begin{array}{l}1.1104^{* *} \\
(4.81)\end{array}$ & $\begin{array}{l}1.033^{* * *} \\
(4.44)\end{array}$ & $\begin{array}{l}1.16301^{* * *} \\
(5.04)\end{array}$ & $\begin{array}{l}1.08662^{* *} \\
(4.66)\end{array}$ & $\begin{array}{l}1.15241^{* * *} \\
(5.00)\end{array}$ & $\begin{array}{l}1.07573^{* *} \\
(4.62)\end{array}$ & $\begin{array}{l}1.0788^{* *} \\
(4.62)\end{array}$ \\
\hline Constant & $\begin{array}{l}-10.98718^{* *} \\
(6.65)\end{array}$ & $\begin{array}{l}-13.35323^{* *} \\
(6.39)\end{array}$ & $\begin{array}{l}-10.97879^{* *} \\
(6.65)\end{array}$ & $\begin{array}{l}-13.34573^{* *} \\
(6.39)\end{array}$ & $\begin{array}{l}-11.14984^{* * *} \\
(6.72)\end{array}$ & $\begin{array}{l}-13.41186^{* *} \\
(6.43)\end{array}$ & $\begin{array}{l}-11.7455^{* *} \\
(7.01)\end{array}$ & $\begin{array}{l}-14.00539^{* *} \\
(6.68)\end{array}$ & $\begin{array}{l}-14.016^{* *} \\
(6.68)\end{array}$ \\
\hline Observations & 91918 & 91918 & 91918 & 91918 & 91918 & 91918 & 91918 & 91918 & $-6.86489^{* *}$ \\
\hline Number of banks & 12936 & 12936 & 12936 & 12936 & 12936 & 12936 & 12936 & 12936 & $(9.54)$ \\
\hline Chi square & 811.02 & 812.08 & 810.77 & 811.84 & 826.08 & 827.42 & 825.58 & 826.94 & 827.24 \\
\hline
\end{tabular}

Two-tail for controls, one-tail for hypothesized effects; Absolute value of $z$ statistics in parentheses.

Significant at 5\%.

** Significant at $1 \%$.

that banks with high CRA ratings, i.e. those that are serving their communities well, are constrained in their pursuit of acquisitions out of fear of jeopardizing their clean records. While other institutional research on effects of legal ambiguity has shown how ambiguity provides opportunity for interested organizations (Edelman, 1990, 1992), in our case, because the CRA rating is ambiguous there is considerable risk and uncertainty involved in acquisitions for highly rated firms. Thus, this federal legislation has the dual effect of encouraging banks to improve their ratings but suppressing acquisition activity among banks that earn the highest ratings.

The supplementary results comparing low and high CRA ratings further suggest that the intended and unintended effects of CRA regulation on acquisition activity are contingent on whether acquisition targets are in the same state or in different states. These models showed that low CRA-rated banks are significantly less likely than high-rated banks to perform withinstate acquisitions but not out-of-state acquisitions. The difference may result from different behavior of either type of bank (or of both types) in those two contexts. Banks with low CRA ratings may feel more constrained in within-state acquisitions because in those cases the banks may face greater local opposition than they do when they intend to acquire banks in more distant acquisitions where the reputation of the bank may be less known. On the other hand, banks with high CRA ratings may be more constrained in out-of-state acquisitions because in distant locations they would benefit less from the local goodwill engendered by their CRA activities. These contingent effects reinforce the overarching theme of the paper, which suggest that there are important state-level influences on the effects of federal regulation on bank acquisitions.

Furthermore, an important part of the story is how states have actively helped banks deal with this ambiguity by providing a tool to help them address their CRA obligations. We highlight how a key tension underlies state activities in that they are both protectors of the public good and facilitators of local economies. They achieve this second goal in part by encouraging bank consolidation within their borders, thus shaping banking behavior and industry structure. As noted, banks can fulfill the mandate of "serving" low-income communities in various ways. The main approaches used in the late 1970s and early 1980s were philanthropy and charitable activities. Then, in the late-1980s, the Low Income Housing Tax Credit (LIHTC) changed how corporations met CRA obligations. Investing in low-income communities became one of the primary ways for banks to boost their CRA ratings. States control the level of LIHTC activity within their borders. Those that have taken an activist approach to using the LIHTC to foster the development of low-income housing are better sites for capital 
consolidation because they host a set of lucrative resources for banks to meet their CRA obligations. Our qualitative data, indicates the LIHTC is influential in addressing CRA performance for acquisitions approvals. Our statistical results show that states that actively promote markets for LIHTCs and the development of low-income housing are thus more attractive for bank acquisitions, and that states that do not essentially (though perhaps unwittingly) drive banks out. This case illuminates the complexities of states' responsibilities with regard to creating a positive environment for the corporate sector and simultaneously allocating resources for the provision of public goods.

Theoretically, we have utilized the tools of organizational theory to unpack this tension and better understand how differing layers of social regulation can have unintended effects. Over the last 20 years, organizational theory has shown a significant amount of evidence that corporations respond to shifting institutional environments by experimenting with new practices that are then affirmed by the regulatory bodies they face (Kalev et al., 2006; see also Edelman, 1990, 1992). And we further show here that ambiguous regulations can serve as a constraint on corporate activities. There have also been growing bodies of work showing that individual states also create different local institutional arrangements to attract and regulate capital (Marquis and Huang, 2009). What we add to this literature is the argument that there is a dynamic nature to this relationship in which not only corporations, but also states seize upon opportunities-for example a change in the tax code that was originally intended for a different purpose-to find creative ways to consolidate and retain capital within their borders. When ambiguous regulations are passed, corporations must find ways to comply with the regulatory pressures they face. In some cases, their creative solutions to these problems can be best facilitated by states, which have the resources and local regulatory power to take advantage of certain institutional opportunities.

While the evolution of the institutional arrangements described here are in many ways specific to the banking industry and the specific institutions that emerged to deal with the crisis of urban America in the middle of the 20th century, we feel the general model that we have presented is quite generalizable. An implication of our research that applies more broadly is that the following stages are important to understanding organizational response to US federal legislation and the regulation of industries: (1) the Federal government produces legislation that mandates general types of firm behaviors; (2) corporations then seek creative ways to comply with this legislation; (3) states, like firms have interests in finding solutions to regulation because they want to consolidate and retain capital within corporations into their borders. So states sometimes play a role in this process by passing legislation or adopting institutional strategies that help corporations navigate the pressures of the federal landscape. While our case is specific to the banking industry, the process we describe here can be found in the evolution of many other institutional fields.

Take, for example, the historical evolution of labor laws in the United States. In 1935, the federal government passed the National Labor Relations Act (Wagner Act), guaranteeing workers the rights to unionize and engage in collective bargaining. For 12 years, this Act defined labor relations in the United States. However, under growing pressure from corporations to limit union power, the House and Senate pushed forward the Taft-Hartley Amendment (over Truman's veto), a provision that then established the framework for states to pass right-to-work statutes, effectively limiting union power in their jurisdictions, an institutional change that 21 states had taken advantage of by 1965. There is a large literature and longstanding debate over the actual effects of Taft-Hartley and right-to-work statutes on state economies (Cebula, 1983; Green, 1951; Lumsden and Petersen, 1975; Palomba and Palomba, 1971; Reynolds and Edwards, 1986; Witte, 1948). However, the more general issues we are interested in here are the multiple layers of institutions and the various organizational and institutional actors that have come together to shape the current system.

Our results show that when one regulator (the state) has a vested interest in an outcome pursued by a corporation (an acquisition) that is controlled by another regulator (say, the Federal Reserve), the situation lends itself to those two regulators working at cross-purposes. Having multiple regulators, each with conflicting interests and goals, is a recipe for a business, which tends to have much sharper objectives, to develop more latitude to get its way, perhaps by co-opting one of the regulators, or by setting one against the other. Additionally, one of the regulators may upstage the other by aligning its goals with the business and by facilitating the exploitation of the ambiguities inherent in the policies of the other regulator.

Questions suggested by this study for future research include: What are the conditions under which state and national governments coordinate and integrate their goals, and present a unified front to their constituencies, rather than work at cross-purposes? Under what conditions will corporations play one regulator against the other in order to receive the greatest amount of autonomy and incentives? When multiple regulators with diverse goals have an interest in certain corporations, how can they best incentivize socially conscious corporate behavior? And further, under what conditions will regulation at one level produce unintended consequences that will jeopardize a mechanism of social legislation at another level?

Corporations and states are often engaged in a complex dance choreographed, on the one hand, to attract capital and, on the other, to limit or regulate certain aspects of corporate behavior. States have both a regulatory mission to serve the public interest and economic incentives to facilitate activity that conflicts with other regulations. The broader historical narrative of which this case is part suggests that for much of US history banks have grown by circumventing laws intended to restrict their locations and expansion, and that self interested states and state agencies have played a behind the scenes role in facilitating this growth.

\section{References}

Affordable Housing, 2009. <http://www.housingfinance.com/ahf/articles/2009/feb/0209-equity-buyersmarket.htm>. Bank of America, 2004. Investing in Our Communities, Document \#00-25-3925B. 
Bebchuk, L.A., 1992. Federalism and the corporation: the desirable limits on state competition in corporate law. Harvard Law Review 105, 1435-1510.

Berger, A., Kashyap, A., Scalise, J., 1995. The transformation of the US banking industry: what a long, strange trip it's been. In: Brainard, W., Perry, G.L. (Eds.), Brookings Papers on Economic Activity. Brookings Institution, Washington, pp. 55-218.

Campbell, J.L., Lindberg, L.N., 1990. Property rights and the organization of economic activity by the state. American Sociological Review 55, $634-647$.

Cebula, R.J., 1983. Right-to-work laws and geographic differences in living costs: an analysis of effects of the 'union shop' ban for the years 1974, 1976, and 1978. American Journal of Economics and Sociology 42, 329-340.

Conference of State Bank Supervisors, Bi-annual, Beginning in 1965. A Profile of State-Chartered Banking. In: Conference of State Bank Supervisors, Washington, DC

Davis, G.F., Mizruchi, M.S., 1999. The money center cannot hold: commercial banks in the US system of corporate governance. Administrative Sciences Quarterly 44, 215-239.

Davis, G.F., Stout, S.K., 1992. Organization theory and the market for corporate control: a dynamic analysis of the characteristics of large takeover targets, 1980-1990. Administrative Sciences Quarterly 37, 605-633.

Davis, G.F., Diekmann, K.A., Tinsley, C.H., 1994. The decline and fall of the conglomerate firm in the 1980s: the deinstitutionalization of an organizational form. American Sociological Review 59, 547-570.

Dehejia, R.H., Lleras-Muney, A., 2003. Why Does Financial Development Matter? The United States from 1900 to 1940. NBER Working Paper No. W9551. <http://ssrn.com/abstract=386180>.

Dobbin, F., Dowd, T.J., 1997. How policy shapes competition: early railroad foundings in Massachusetts. Administrative Science Quarterly 42, 501-529.

Dobbin, F., Dowd, T.J., 2000. The market that antitrust built: public policy, private coercion, and railroad acquisitions, 1825 to 1922 . American Sociological Review 65, 631-657.

Dobbin, F., Sutton, F.R., 1998. The strength of a weak state: the rights revolution and the rise of human resources management divisions. The American Journal of Sociology 104, 441-476.

Dobbin, F., Sutton, J., Meyer, J., Scott, W.R., 1993. Equal opportunity law and the construction of internal labor markets. American Journal of Sociology 99, $396-427$.

Edelman, L.B., 1990. Legal environments and organizational governance: the expansion of due process in the American Workplace. American Journal of Sociology 95, 1401-1440.

Edelman, L.B., 1992. Legal ambiguity and symbolic structures: organizational mediation of civil rights law. American Journal of Sociology 97, 1531-1576.

Federal Reserve, May, 1996. Federal Reserve Bulletin 445. US Government Printing Office, Federal Reserve Board.

Federal Reserve, Spring, 2004. Federal Reserve Bulletin; Legal Developments. Federal Reserve Board, US Government Printing Office, pp. $212-248$.

Fettig, D., 1993. In Light of Public Disclosure, CRA Gains Luster. But after 15 years, Banking Industry Still Takes Dim View, Fedgazette. Federal Reserve Bank of Minneapolis, Minneapolis.

Fligstein, N., 1990. The Transformation of Corporate Control. Harvard University Press, Cambridge.

Green, W., 1951. The Taft-Hartley act: a critical view. Annals of the American Academy of Political and Social Science 274, $200-205$.

Guthrie, D., 2004. An accidental good: how savvy social entrepreneurs seized on a tax loophole to raise billions of corporate dollars for affordable housing. Stanford Social Innovation Review 34, 44.

Guthrie, D., McQuarrie, M., 2005. Privatization and the social contract: corporate welfare and low-income housing in the United States since 1986. Research in Political Sociology 14, 15-51.

Guthrie, D., McQuarrie, M., 2006. Houses for the poor and a new business for banks: the creation of a market for affordable housing. In: Rangan, V.K., Quelch, J.A., Herrero, G. (Eds.), Business Solutions for the Social Poor: Creating Social and Economic Value. Jossey-Bass, San Francisco.

Guthrie, D., McQuarrie, M., 2007. Corporate investment, social innovation, and community change: the local political economy of low-income housing development. Journal of City and Community.

Guthrie, D., Roth, L.M., 1999a. The state, courts, and equal opportunities for female CEOs in US organizations: specifying institutional mechanisms. Social Forces 78, 511-542.

Guthrie, D., Roth, L.M., 1999b. The state, courts, and maternity policies in US organizations: specifying institutional mechanisms. American Sociological Review 64, 41-63.

Hausman, J.A., 1978. Specification tests in econometrics. Econometrica 46, 1251-1271.

Haveman, H.A., 1993. Organizational size and change: diversification in the savings and loan industry after deregulation. Administrative Science Quarterly 38, 20-50.

Haveman, H.A., Rao, H., 1997. Structuring a theory of moral sentiments: institutional and organizational coevolution in the early thrift industry. The American Journal of Sociology 102, 1606-1651.

Hossain, R., 2004. The Past, Present and Future of the Community Reinvestment Act (CRA): A Historical Perspective. University of Connecticut, Department of Economics Working Paper Series 2004-30.

Jepperson, R., Meyer, J., 1991. The public order and the construction of formal organizations. In: Powell, W.W., DiMaggio, P. (Eds.), The New Institutionalism in Organizational Analysis. University of Chicago Press, Chicago, pp. 204-231.

Johnson, S.A., Sarkar, S.K., 1996. The valuation effects of the 1977 Community Reinvestment Act and its enforcement. Journal of Banking \& Finance 20, $783-$ 803.

Kalev, A., Dobbin, F., Kelly, E., 2006. Best practices or best guesses? Assessing the efficacy of corporate affirmative action and diversity policies. American Sociological Review 71, 589-617.

Lounsbury, M., Hirsch, P., Klinkerman, S., 1998. Institutional upheaval and performance variation: a theoretical agenda and illustration from the deregulation of commercial banks. In: Baum, J.A.C., (Ed.), Advances in Strategic Management, pp. 129-146.

Lumsden, K., Petersen, C., 1975. The effect of right-to-work laws on unionization in the United States. The Journal of Political Economy 83, $1237-1248$.

Macey, J.R., Miller, G.P., 1993. The community reinvestment act: an economic analysis. Virginia Law Review 79, $291-348$.

Marquis, C., Huang, Z., 2009. The contingent nature of public policy and the growth of U.S. commercial banking. Academy of Management Journal 52, 12221246

Marquis, C., Huang, Z., 2010. Acquisitions as exaptation: the legacy of founding institutions in the U.S. commercial banking industry. Academy of Management Journal 53, 1441-1473.

Marquis, C., Lounsbury, M., 2007. Vive la resistance: consolidation and community-level professional counter-mobilization in US banking. Academy of Management Journal 50, 799-820.

Marquis, C., Glynn, M.A., Davis, G.F., 2007. Community isomorphism and corporate social action. Academy of Management Review $32,925-945$.

Marsico, R., 2005. Democratizing Capital: The History, Law, and Reform of the Community Reinvestment Act. Carolina Academic Press, Durham, NC.

Massey, D.S., Denton, N.A., 1992. American Apartheid: Segregation and the Making of the Underclass. Harvard University Press, Cambridge, Mass.

McKinley, V., 1994. Community Reinvestment Act: ensuring credit adequacy or enforcing credit allocation? Regulation 4, $25-37$.

Mizruchi, M.S., 1992. The Structure of Corporate Political Action: Interfirm Relations and their Consequences. Harvard University Press, Cambridge.

Mizruchi, M.S., Fein, L.C., 1999. The social construction of organizational knowledge: a study of the uses of coercive, mimetic and normative isomorphism. Administrative Sciences Quarterly 44, 653-683.

Palmer, D., Barber, B., Zhou, X., Soysol, Y., 1995. The friendly and predatory acquisition of large US corporations in the 1960s: the other contested terrain. American Sociological Review 60, 469-499.

Palomba, C.A., Palomba, N.A., 1971. Right-to-work laws: a suggested economic rationale. Journal of Law and Economics $14,475-483$.

Pilloff, S.J., 2004. Bank Merger Activity in the United States, 1994-2003. Board of Governors of the Federal Reserve System, Washington, DC.

Powell, W.W., DiMaggio, P., 1991. The New Institutionalism in Organizational Analysis. University of Chicago Press, Chicago. 
Reynolds, M.O., Edwards, M., 1986. Right-to-work laws and geographic differences in living costs: comment. American Journal of Economics and Sociology 45, 247-252.

Rhoades, S.A., 2000. Bank Mergers and Banking Structure in the United States, 1980-1998, Staff Study 174. Board of Governors of the Federal Reserve System, Washington, DC.

Roe, M.J., 1994. Strong Managers, Weak Owners: The Political Roots of American Corporate Finance. Princeton University Press, Princeton.

Romano, R., 1987. The state competition debate in corporate law. Cardozo Law Review 8, 709-757.

Romano, R., 1993. The Genius of American Corporate Law. AEI Press, Washington, DC.

Roy, W., 1997. Socializing Capital: The Rise of the Large Industrial Corporation in America. Princeton University Press, Princeton, N.J.

Scheiber, H.N., 1981. Regulation, property rights, and definition of “the market": law and the American economy. The Journal of Economic History 41, 103109.

Schneiberg, M., Bartley, T., 2001. Regulating American industries: markets, politics, and the institutional determinants of fire insurance regulation. American Journal of Sociology 107, 101-146.

Simpson, W.G., Kohers, T., 2002. The link between corporate social and financial performance: evidence from the banking industry. Journal of Business Ethics 35, 97-109.

Stearns, L.B., Allan, K.D., 1996. Economic behavior in institutional environments: the corporate merger wave in the 1980s. American Sociological Review 61, 699-718

Steiner, P.O., 1975. Mergers: Motives, Effects, Policies. University of Michigan Press, Ann Arbor.

Stiroh, K.J., Strahan, P., 2003. Competitive dynamics of deregulation: evidence from US banking. Journal of Money, Credit and Banking 35, 801-828.

Such, C., 2002. Low Income Housing Tax Credits. Community Investments: A Publication of the Community Affairs Unit of the Federal Reserve Bank of San Francisco, vol. 14, pp. 3-7.

Sutton, J.R., Dobbin, F., 1996. The two faces of governance: responses to legal uncertainty in US firms, 1955 to 1985. American Sociological Review 61, 794811.

Sutton, J.R., Dobbin, F., Meyer, J.W., Scott, W.R., 1994. The legalization of the workplace. American Journal of Sociology 99 , $944-971$.

United States Congress, 1968. The Fair Housing Act [42 United States Congress §§ 3601-3619].

United States Congress, 1974. The Equal Credit Opportunity Act [15 United States Congress $§ \S 1691-1691 \mathrm{f}]$.

United States Congress, 1975. The Home Mortgage Disclosure Act [12 United States Congress $\S \S 2801-2809]$ ].

United States Congress, 1977. The Community Reinvestment Act [12 United States Congress $\S \S 2901-2908]$.

US Bank, 2005. US Bank Receives 'Outstanding' CRA Rating for Its Efforts in Greater Cincinnati. <http://phx.corporate-ir.net/ phoenix.zhtml?c=117565\&p=irol-newsArticle\&ID=667629\&highlight> (accessed 22.06.07).

Venkatesh, S.A., 2000. American Project: The Rise and Fall of a Modern Ghetto. Harvard University Press, Cambridge, Mass.

Wade, J.B., Swaminathan, A., Saxon, M.S., 1998. Normative and resource flow consequences of local regulations in the American brewing industry, 18451918. Administrative Science Quarterly 43, 905-935.

Wheelock, D.C., Wilson, P.W., 2001. Consolidation in US Banking: Who Are the Acquirers? Working Paper 2001-003A, The Federal Reserve Bank of St. Louis. Wilson, W.J., 1987. The Truly Disadvantaged: The Inner City, the Underclass, and Public Policy. University of Chicago Press, Chicago.

Witte, E.E., 1948. An appraisal of the Taft-Hartley Act. The American Economic Review 38, 368-382.

Zorn, D.M., 2004. Here a chief, there a chief: the rise of the CFO in the American firm. American Sociological Review 69, $345-364$. 